\title{
Case Study: The SpareBank 1 Gruppen's Road to a New Corporate Governance Based on the Principles of beyond Budgeting
}

\author{
Sigurd Aune \\ SpareBank 1 Gruppen, Oslo, Norway \\ sigurd.aune@sparebank1.no
}

\begin{abstract}
SpareBank 1 Gruppen is a Norwegian holding company that, through its subsidiaries, provides and distributes products in the field of life and P\&C insurance, fund management, securities brokering and factoring. The company joined the BBRT in 2008. Sigurd Aune, CFO SpareBank 1 Gruppen will describe their Going Dynamic (Beyond Budgeting) project. This will include why they needed to change, what they are changing, their progress so far and the challenges that lie ahead.
\end{abstract}

